\title{
New records for helminths of hystricognath rodents from the middle and high Rio Negro microregion, State of Amazonas, Brazil
}

\author{
Alessandra Q. Gonçalves ${ }^{1,}$; ; Márcio N. Bóia ${ }^{1}$; José R. Coura ${ }^{1}$ \& Roberto M. Pinto ${ }^{2,3}$ \\ ${ }^{1}$ Laboratório de Doenças Parasitárias, Departamento de Medicina Tropical, Instituto Oswaldo Cruz. Avenida Brasil 4365, \\ 21045-900 Rio de Janeiro, Rio de Janeiro, Brasil. \\ 2 Laboratório de Helmintos Parasitos de Vertebrados, Departamento de Helmintologia, Instituto Oswaldo Cruz. \\ Avenida Brasil 4365, 21045-900, Rio de Janeiro, Rio de Janeiro, Brasil. \\ ${ }^{3}$ Corresponding author. CNPq research fellow. E-mail: rmpinto@ioc.fiocruz.br
}

\begin{abstract}
Four nematodes and one cestode species from three Brazilian agoutis - two Dasyprocta fuliginosa Wagler, 1832 and one Dasyprocta leporina (Linnaeus, 1758) - and six pacas - Agouti paca (Linnaeus, 1766) - captured in tributaries rivers in the middle and high Rio Negro microregion, State of Amazonas, Brazil, were studied. The nematodes Physaloptera torresi (Travassos, 1920) Ortlepp, 1922, Physocephalus mediospiralis (Molin, 1859) Hall, 1916 and the cestode Raillietina (R.) trinitatae (Cameron \& Reesal, 1951) Baer \& Sandars, 1956 are reported from the State of Amazonas for the first time. The studied helminths (the nematodes P. torresi, P. mediospiralis, Trichuris gracilis (Rud., 1819) Hall, 1916, Helminthoxys urichi (Cameron \& Reesal, 1951) Hugot, 1986 and the cestode R. (R.) trinitatae) represent new host record for Dasyprocta fuliginosa. New morphometric data and remarks about each species are provided. KEY WORDS. Amazon; cestodes; mammals; nematodes; rain forest.
\end{abstract}

RESUMO. Novos registros para helmintos de roedores histricognatos da microrregião do médio e alto Rio Negro, Estado do Amazonas, Brasil. Foram estudadas quatro espécies de nematóides e uma de cestóide coletados de três cutias - duas Dasyprocta fuliginosa Wagler, 1832 e uma Dasyprocta leporina (Linnaeus, 1758) - e seis pacas Agouti paca (Linnaeus, 1766) - capturadas em rios afluentes na microrregião do médio e alto Rio Negro, Estado do Amazonas, Brasil. Os nematóides Physaloptera torresi (Travassos, 1920) Ortlepp, 1922, Physocephalus mediospiralis (Molin, 1859) Hall, 1916 e o cestóide Raillietina (R.) trinitatae (Cameron \& Reesal, 1951) Baer \& Sandars, 1956 são registrados pela primeira vez no Estado do Amazonas. Os helmintos estudados (os nematóides $P$. torresi, $P$. mediospiralis, Trichuris gracilis (Rud., 1819) Hall, 1916, Helminthoxys urichi (Cameron \& Reesal, 1951) Hugot, 1986 e o cestóide $R .(R$.$) trinitatae) representam novos registros para Dasyprocta fuliginosa. Novos dados morfométricos e$ observações sobre cada espécie são fornecidos.

PALAVRAS-CHAVE. Amazônia; cestóides; floresta tropical; mamíferos; nematóides.

In an overall analysis, studies of the helminth fauna of non-human vertebrates from the Amazon Region are few due to the difficulties to reach the hinterlands and the lack of infrastructure and available information in such localities. Moreover, the positive and rising concern related to the maintenance of the biodiversity of the Amazon forest by means of laws to protect the environment and control the studies in these areas has also to be taken into account. Even though some researchers (Vicente 1964, Pereira \& Machado Filho 1968, Gomes \& Pinto 1978, Pinto \& Gomes 1976, 1980, 1984, Thatcher 1991, GONÇALVES et al. 2002) had contributed to the knowledge of helminth parasites of non-human hosts, there is a lot more to be investigated so far in the Amazon region.

This paper deals with helminths recovered from the hystricognath rodents Dasyprocta fuliginosa Wagler, 1832,
Dasyprocta leporina (Linnaeus, 1758) and Agouti paca (Linnaeus, 1766) captured in tributary rivers in the middle and high Rio Negro microregion, in Barcelos and Santa Isabel do Rio Negro municipalities, State of Amazonas, Brazil.

\section{MATERIAL AND METHODS}

Animals were captured in locations of piassaba palm trees - (Leopoldinia piassaba Wallace, 1853 - maintained in the waterways of the Rios Aracá and Padauiri (left-side tributaries of the Rio Negro, Barcelos municipality) and in Rio Preto (rightside tributary of the Rio Padauiri, Santa Isabel do Rio Negro municipality) (Fig. 1).

Three specimens of agoutis, two of Dasyprocta fuliginosa, and one of Dasyprocta leporina and six of pacas Agouti paca were captured between 2000 and 2002; captures, on account of one 


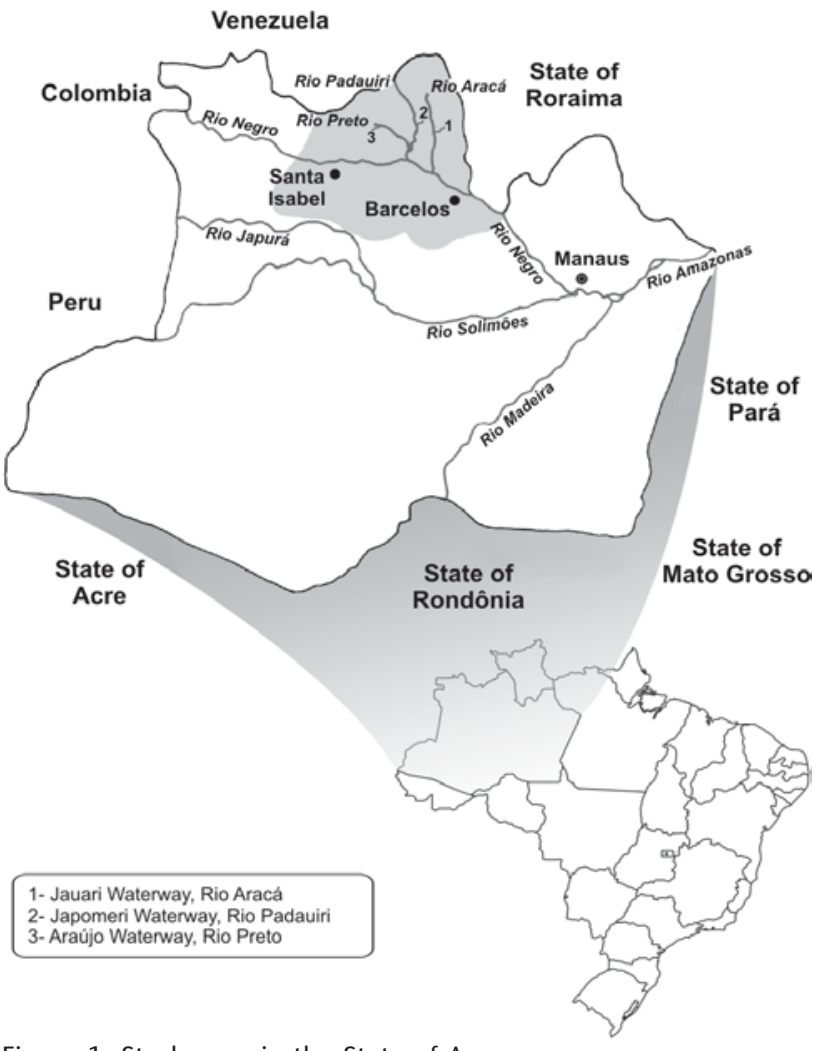

Figure 1. Study area in the State of Amazonas.

of the authors (A.Q.G.), have been authorized by the Brazilian Institute of Environment and Natural Resources - Ibama (process no. 02001.002659/97-02, license no. 056/2000 - DIFAS/ DIREC (validity 01/04/00 to $01 / 04 / 01$ ) and no. 021/2002 COEFA (validity 22/01/2002 to 22/04/2002). Animals were identified by taxidermists and deposited in the National Museum of Rio de Janeiro, Brazil.

Stomach, small and large intestines and abdominal cavity of the rodents were examined for helminths. Nematodes were briefly rinsed alive in a $0.85 \% \mathrm{NaCl}$ solution and fixed in hot AFA $\left(70^{\circ}\right.$ GL ethanol, 93\%; formaldehyde, 5\%; glacial acetic acid, 2\%) and were preserved in the same solution. Cestodes were rinsed in the saline solution referred previously, kept in tap water in the refrigerator overnight and fixed in cold AFA.

Nematodes were dehydrated in an ethanol series, clarified unstained in phenol and kept as whole mounts in a beechwood creosote and balsam solution 1:1. "En face" jelly mounts were obtained in accordance with the method of ANDERSON (1958). Cestodes were stained with Langeron's carmine or Delafield's hematoxylin, differentiated in a 0,5\% chloridric ethanol, dehydrated in an ethanol series, clarified in beechwood creosote and kept as whole mounts in Canada balsam (Амато 1985).

Classification of the nematodes is in accordance with Vicente et al. (1997) and that of cestodes follows Jones \& BRAY
(1994). Measurements are in millimeters. NHR and NLR are for New Host Record and New Locality Record, respectively. Photomicrographs were obtained in a brightfield Zeiss microscope in a Differencial Interference Contrast (DIC) apparatus. Helminth samples were deposited in the Helminthological Collection of the Oswaldo Cruz Institute (CHIOC), either as wet material or whole mounts. Some presently studied and identified species were compared with specimens previously deposited in the CHIOC.

\section{RESULTS}

\section{Nematoda}

\section{Trichinelloidea, Trichuridae Trichuris gracilis (Rud., 1819) Hall, 1916 Figs 2,3}

In the three necropsies of the agoutis, twenty-four female specimens were recovered. Morphometrics based on eleven specimens. Morphometric data on worms from $D$. fuliginosa are in parentheses.

Body 45.25-57.19 (40.84-54.98) long, with a maximum width of 0.61-0.65 (0.49-0.70) at the posterior portion. Esophagus (anterior portion) 27.95-38.15 (25.74-35.26) long and posterior portion 15.98-21.76 (15.10-21.52) long, with a ratio of 1.6-2.1 (1.55-1.94). Width of the esophagus at the anterior region $0.070(0.070-0.098)$, at the middle portion $0.112-0.126$ (0.126-0.154), at the junction with the intestine 0.266-0.322 (0.224-0.302). Vulva slightly posterior $0.042-0.070$ to the level of the esophagus-intestine junction or, in some specimens, located just at this junction. Vulvar opening 15.95-21.70 to the posterior extremity. Ovejetor (vagina vera) 2.53-3.37 (1.85-2.69) long. Rectum 0.27-0.34 (0.27) long. Eggs 0.050-0.054 (0.046$0.050)$ long, 0.022 (0.021) wide. Anus sub-terminal, 0.036-0.043 (0.042-0.056) from the posterior end.

Taxonomic summary. Host: D. leporina, (necropsy CHIOC no. 26463); Mammalia, Rodentia, Dasyproctidae; common name: Brazilian agouti, "cutia"; site of infection: cecum; localities: Ucuqui settlement, Jauari waterway, left margin of the Rio Aracá, Barcelos municipality (GPS 00.14.25N, 63.25.00W); collected in April 27, 2000. Host: D. fuliginosa (necropsies CHIOC no. 26464-26465) - NHR; common names: Brazilian agouti, "cutia"; site of infection: cecum; localities: Quebra cabeça settlement, Araújo waterway, right margin of the Malalarrá waterway, right margin of the Rio Preto, Santa Isabel do Rio Negro municipality (GPS 00.03.50 N, 64.35.41W); Três Barracas settlement, Jauari waterway, left margin of the Rio Aracá, Barcelos municipality; collected: February 26, 2001 and February 06, 2002.

Deposited specimens: CHIOC no. 34847-34849 (wet material) and 35046 a-f, 36629 a-e (whole mounts).

Remarks: taking into account that no males of this species are available so far (CAMERON \& ReESAL 1951, GonçALVES et al. 2002), the presently studied samples were identified to Trichuris gracilis considering that this species is the only of the genus de- 

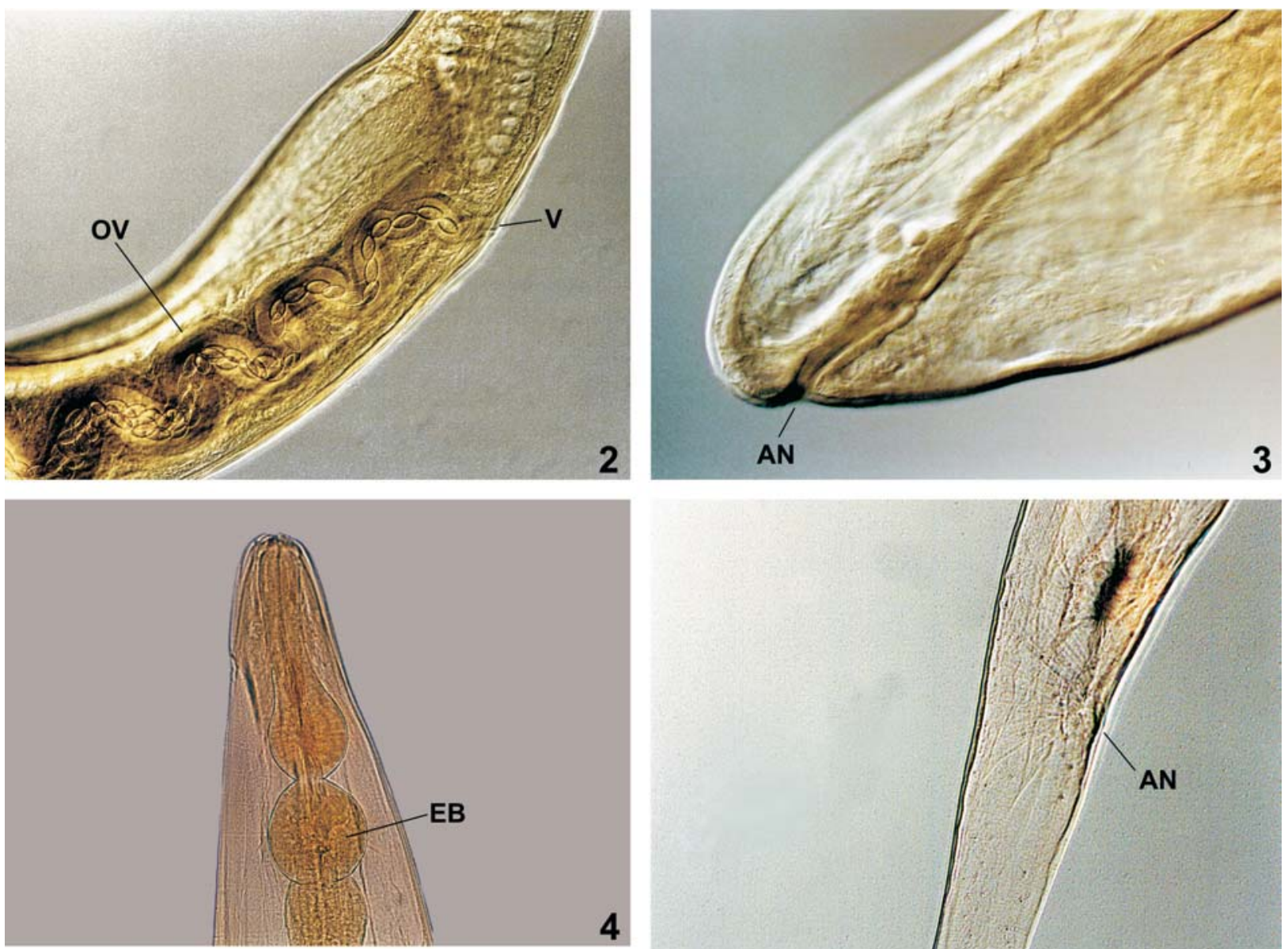

4
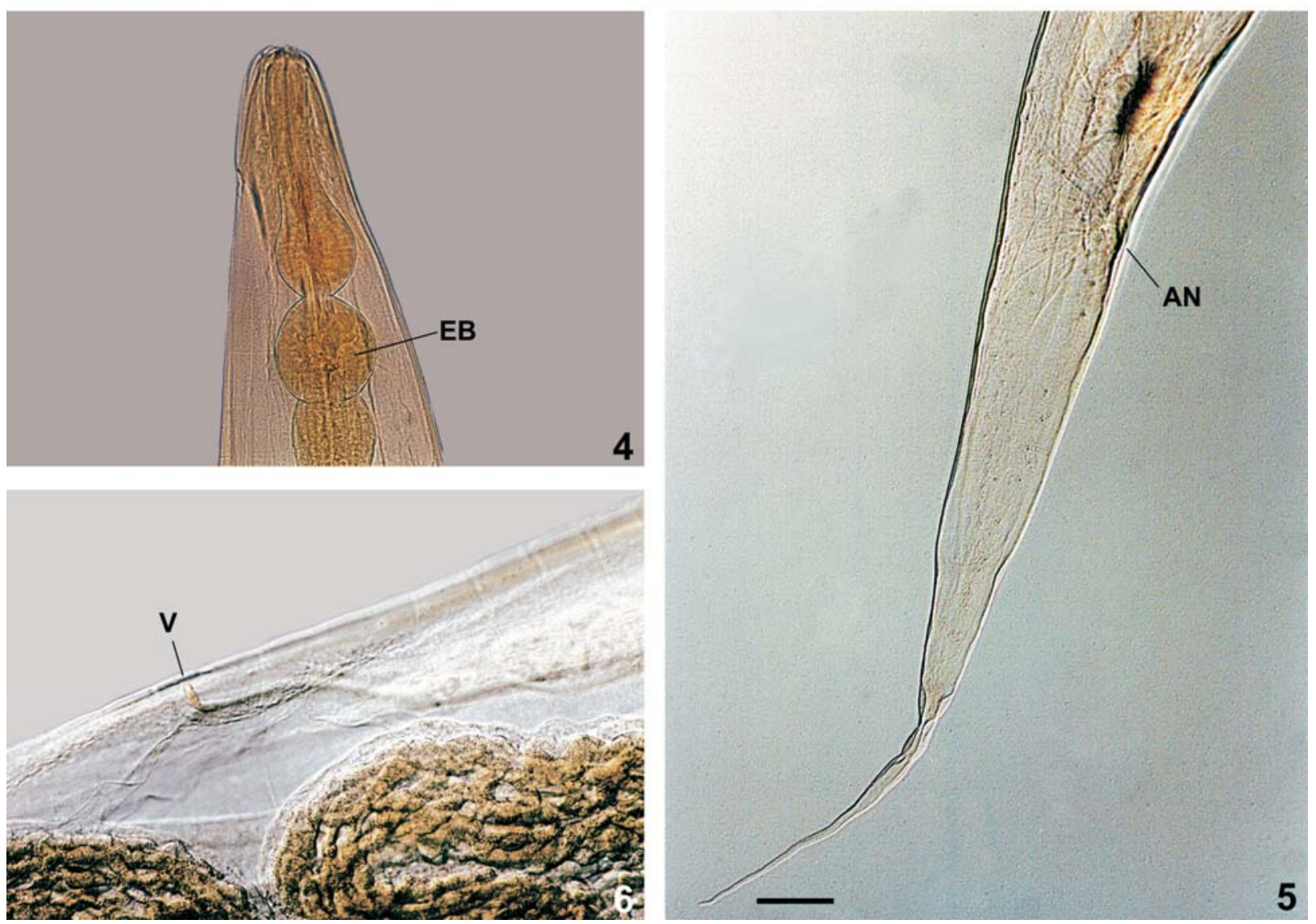

Figures 2-6. Trichuris gracilis (2) vulvar opening (V) and ovejector (OV), lateral view; (3) posterior extremity with anal opening (AN), lateral view; Helminthoxys urichi (4) esophagus of female with esophageal bulb (EB), ventral view; (5) posterior extremity of female with anal aperture (AN), lateral view; (6) Detail of the vulva $(\mathrm{V})$, lateral view. Bar of figure 5 (common to figures $2,3,4,6)=0.05 \mathrm{~mm}$ in figure $6,0.06 \mathrm{~mm}$ in figure $3,0.1 \mathrm{~mm}$ in figure $5,0.13 \mathrm{~mm}$ in figures 2 and 4.

scribed from Dasyproctidae hosts. It was proposed by RuDOLPHI (1819) on the basis of female specimens recovered from $D$. leporina in Brazil (type locality). Cameron \& ReEsal (1951) re- described T. gracilis from the same host in Trinidad and allocated the species as Trichuris gracilis var. trinitatae, considering the body size and length of the posterior portion of the body

Revista Brasileira de Zoologia 23 (3): 716-726, setembro, 2006 
when compared to data after RudoLPHI (1819), also considering the former species as Trichuris gracilis var. gracilis. In the species examined by CAMERON \& REESAL (1951), the body length varied from 38.56 to 39.62 and the posterior portion from 15.10 to 18.40 , whereas in those reported by RuDOLPHI (1819), these values were 47.0-54.0 and 22.0-26.0, respectively. Samples studied here are closer to $T$. gracilis var. gracilis due to the total body length. Conversely, the length of the posterior portion of the body is closer to that described for $T$. gracilis var. trinitatae, suggesting that variations may not be taken into account and that differences are due to the physiological conditions of the host and to a process of parasite adaptation. This species was previously referred in Dasyprocta leporina (Linnaeus) from Manaus, State of Amazonas, Brazil (GonÇALVEs et al. 2002).

\section{Oxyuroidea, Oxyuridae}

\section{Helminthoxys urichi (Cameron \& Reesal, 1951) Hugot, 1986}

\section{Figs 4-7}

About one hundred females and five male specimens were recovered from one agouti. Morphometrics based on five males and five females.

Males: body 3.95-5.09 long, 0.27-0.35 wide. Cephalic alae 0.21-0.31 long, buccal capsule 0.01-0.02 in depth. Esophagus 0.34-0.48 long and bulb 0.10-0.15 in diameter. Nerve ring and excretory pore $0.11-0.16$ and $0.85-0.91$ from the anterior end, respectively. Single spiculum 0.22-0.37 long. Gubernaculum 0.04 long. Cloacal aperture 0.34-0.42 from the posterior extremity. Anterior and posterior cuticular "mamelons" 0.11-0.13 long, 0.018-0.04 wide. Anterior and posterior "mamelons" 1.411.57 and 0.96-1.08 from the cloacal aperture, respectively. Caudal terminal filament 0.22-0.35 long.

Females: body 7.56-9.08 long, 0.43-0.57 wide. Cephalic alae 0.19-0.35 long. Esophagus 0.49-0.59 long and bulb 0.150.18 in diameter. Nerve ring and excretory pore 0.15-0.21 and 1.30-1.42 from the anterior end, respectively. Vulva located in the posterior third of the body, 1.58-1.95 from the anal aperture. Ovejector (vagina vera) vestigial, thin walled. Anus 0.961.07 from the posterior extremity. Eggs 0.076-0.090 long, 0.0400.043 wide.

Taxonomic summary. Host: Dasyprocta fuliginosa (necropsy CHIOC $\left.n^{\circ} 26465\right)$ - NHR; Site of infection: cecum; locality: Três Barracas settlement, Jauari waterway, left margin of the Rio Aracá, Barcelos municipality; collected: February 06, 2002.

Deposited specimens: CHIOC no. 34872 (wet material) and 35060 a-f (whole mounts).

Remarks: the original description of $H$. urichi was based on specimens parasitizing Dasyprocta leporina from Trinidad island by CAMERon \& ReEsal (1951) and was firstly legally reported in Brazil by PINTO \& Gomes (1980) in an specimen of Dasyprocta sp. captured in the Km 47 of the Manaus - Itacoatiara road, State of Amazonas.

Species of the genus Helminthoxys Freitas, Lent \& Almeida,
1937 differ from those allocated in Syphacia Seurat, 1916 due to the presence of interlabia in specimens of the former group; in the case of $H$. urichi these formations are, in fact, hypertrophied finger-like lips in accordance with the description of Cameron \& Reesal (1951).

Hugot (1986) studied the morphology of $H$. urichi recovered from $D$. leporina captured in the French Guyana and described, as particularities of specimens of the genera Helminthoxys and Octodonthoxys Quentin, Courtin \& Fontecilla, 1975 (parasitizing neotropical caviomorphs), the presence of two cuticular "mamelons" with the function to secrete a viscous substance to attach the male to the female during the copula. Moreover, there was reference to the vestigial vagina vera situated in the posterior third of the body; this character is only observed in specimens of $H$. urichi and $H$. freitasi Quentin, 1969. According to Hugot (1986) the displacement of the vulvar aperture, frequently observed in the anterior third of the body, determined the extension of the vagina vera and also of the spicule in the males.

In the comparison of morphometric data reported by Hugot (1986) and CAMERon \& ReEsAL (1951), it was verified that the distance of the excretory pore from the anterior end in the specimens presently studied is similar to that described by HuGOT (1986) [1.40 in females and 0.83 in males] differing from data after CAMERon \& REesal (1951), that reported to 0.50-0.80 in females and 0.90 in males. The spicular length also varied when compared to that described by Hugot (1986) [0.53] and was bigger than the presently observed [0.22-0.37], the reported by Cameron \& Reesal (1951) [0.23-0.25]. This suggests that either the data after CAMERon \& ReEsaL (1951) (on what concerns to the location of the excretory pore) and HugOT (1986) (in relation to the size of the spicule) were misinterpreted or that these differences are due to intra-specific conditions that can determine a wider range of variation related to the analyzed characters.

\section{Physalopteroidea, Physalopteridae}

\section{Physaloptera torresi (Travassos, 1920) Ortlepp, 1922}

\section{Figs 8-10}

In five necropsies (three agoutis, two pacas) eleven males (one immature, one broken) and twenty-two females (four immature) were recovered.

Morphometrics based on five adults and one immature male and on six adult and four immature females. Data in parentheses refer to $P$. torresi in pacas.

General: "en face" sections of the head of males and females showed two semi-circular lips, each with an inner group of pointed teeth disposed in a trident-like formation and a stout outer-lateral tooth with quadrangular end. One pair of papillae was observed in each lip.

Adult males: body 33.90-45.15 long, 0.80-1.12 wide. Muscular and glandular esophagus $0.42-0.54$ and 4.18-4.90 long, respectively. Nerve ring and excretory pore 0.37-0.49 and 0.88 from the anterior end, respectively. Spicules slightly curved, 

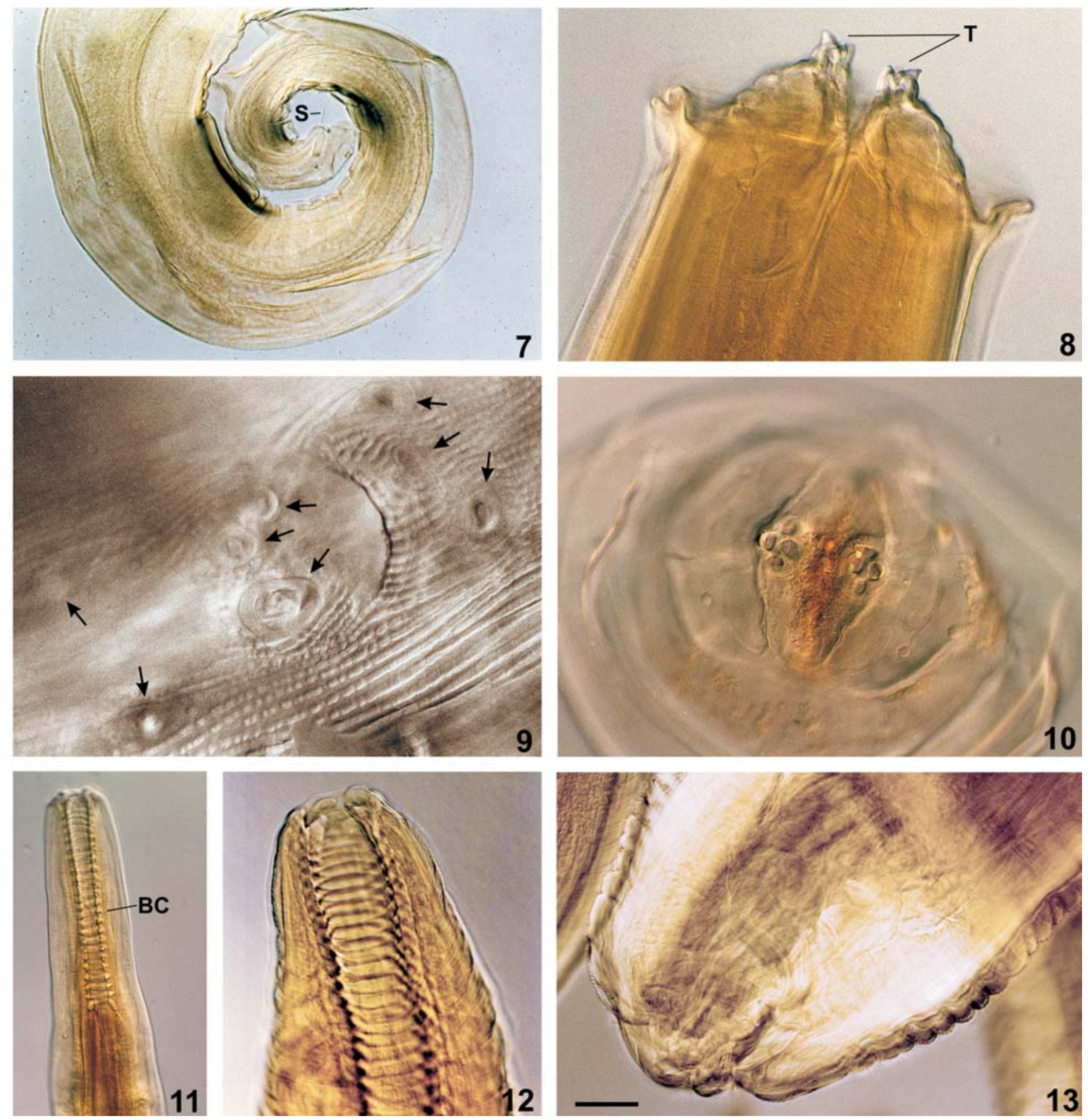

Figures 7-13. Helminthoxys urichi (7) Posterior portion of male, with spicule (S), lateral view; Physalopera torresi (8) cephalic region of male, with teeth $(T)$ arrangement in each lip, ventral view; (9) cloacal region of male, showing pre, ad and post-cloacal papillae (arrows), ventral view; (10) mouth of the female, apical view; Physocephalus mediospiralis (11) anterior portion of female, with buccal capsule (BC), ventral view; (12) detail of the anterior extremity of female, ventral view; (13) posterior extremity of female, lateral view. Bar of figure 13 (common to figures 7 $12)=0.03 \mathrm{~mm}$ in figure $8,0.04 \mathrm{~mm}$ in figure $12,0.06 \mathrm{~mm}$ in figures $10,13,0.07 \mathrm{~mm}$ in figure $9,0.08 \mathrm{~mm}$ in figure $7,0.09 \mathrm{~mm}$ in figure 11.

the left 0.56-0.65 long, the right 0.42-0.57 long. Twenty one caudal papillae: four pairs of pedunculate papillae laterally distributed in the cloacal region $\left[1^{\text {st }}, 2^{\text {nd }}, 3^{\text {rd }}\right.$ and $7^{\text {th }}$ pairs, in ac- cordance with Chabaud \& Petrer (1961)]; three sessile pre-cloacal papillae ( $4^{\text {th }}$ pair); two pairs of aligned sessile papillae, immediately post-cloacal ( $5^{\text {th }}$ and $6^{\text {th }}$ pairs $)$ and three pairs of equi-

Revista Brasileira de Zoologia 23 (3): 716-726, setembro, 2006 
distant sessile papillae in the caudal anterior half $\left(8^{\text {th }}, 9^{\text {th }}\right.$ and $10^{\text {th }}$ pairs). The $10^{\text {th }}$ pair is on a cuticular plaque-like formation, 0.95-1.00 from distal end. Cloacal aperture 1.51-1-89 from the posterior extremity.

Immature male: body 18.46 long, 0.48 wide. Muscular and glandular esophagus 0.49 and 3.45 long, respectively. Left spicule curved, 0.57 long; right spicule straight, 0.39 long. Cloacal aperture 0.89 from the posterior extremity. Distance between the $8^{\text {th }}$ and $9^{\text {th }}$ pairs of caudal papillae 0.07; distance between the $9^{\text {th }}$ and $10^{\text {th }}$ pairs 0.16 ; distance of the $10^{\text {th }}$ pair to the posterior end 0.50. Absence of one pedunculate and one sessile post-cloacal papillae; thus, only three post-cloacal papillae (one bigger than the others) were observed, indicating the immature stage of the specimen.

Adult females: body 11.0-13.0 (11.0-13.0) long, 1.16-1.84 (1.84-2.14) wide. Muscular and glandular esophagus 0.81-0.82 (0.74-0.82) and 7.00-8.20 (9.01-9.52) long, respectively. Nerve ring 0.75-0.78 (0.72-0.77) from the anterior end. Vulvar aperture 6.69-7.92 (5.71-7.41) from the anterior extremity and located anterior to the end of esophagus at a distance of 0.30 1.29 (2.24-4.42). Ovejector, including eggs chamber, 2.89-4.59 (3.91-4.45) long. Eggs (0.043-0.050) long, (0.029) wide. Presence of nine to ten (nine to eleven) uterine braches lacking a common trunk - type $7-15 \mathrm{H}$ in accordance to the classification of Morgan (1947). Anal aperture (1.15-1.52) from the posterior extremity.

Immature female (1): body 10.47 long, 0.27 wide. Glandular esophagus 2.14 long and anal aperture 0.24 from the posterior extremity; genitalia undeveloped.

Immature females (2-4): Body 36.75-50.83 long, 0.83-1.23 wide. Muscular and glandular esophagus $0.57-0.71$ and 5.276.63 long, respectively. Nerve ring and vulvar aperture $0.57-0.70$ and 3.80-4.62 from the anterior end, respectively. Ovejetor 1.54$3.06 \mathrm{long}$, reaching the posterior portion of the esophagus; eleven uterine branches. One of the females presented eggs 0.050 long, 0.025 wide. Anal aperture 0.98 from the posterior extremity.

Taxonomic summary. Hosts: Dasyprocta leporina (necropsies CHIOC no. 26463) Locality: Ucuqui settlement, Jauari waterway, left margin of the Rio Aracá, Barcelos municipality (GPS 00.14.25N, 63.25.00W) - NLR; collected: April 27, 2000. Dasyprocta fuliginosa (necropsies CHIOC no. 26464-26465) NHR, Localities: Quebra Cabeça settlement, Araújo waterway, right margin of the Malalarrá waterway, right margin of Rio Preto, Santa Isabel do Rio Negro municipality (GPS 00.03.50N, 64.35.41W); Três Barracas settlement, Jauari waterway, left margin of the Rio Aracá, Barcelos municipality - NLR; collected in February 26, 2001 and February 06, 2002. Agouti paca (Linnaeus, 1766) (necropsies CHIOC no. 26469-26470); Mammalia, Rodentia, Agoutidae, common name: paca; site of infection: stomach; localities: Sítio da Mamãe settlement, Japomeri waterway, left margin of the Rio Padauiri, Barcelos municipality (GPS 00.20.51N, 64.00.28W); Três Barracas settlement, Jauari waterway, left margin of the Rio Aracá, Barcelos municipality - NLR; collected in March, 10, 2001 and February 08, 2002.

Deposited specimens: recovered from agoutis: CHIOC no. 34873 (wet material), 35061a-b 35062a-c, 35063a-b (whole mounts); recovered from pacas: CHIOC no. 34874, 34875 (wet material) and 35064 (whole mount).

Remarks: Physaloptera torresi is a species that parasitizes Dasyproctidae and Agoutidae hosts and was described by Travassos (1920) on the basis of specimens recovered from $A$. paca in the State of Bahia, Brazil. OrTLEPP (1922), re-studied this species based on data obtained by Travassos (1920), and later proposed a key to the identification of species of the genus Physaloptera Rudolphi, 1819 allocating P. torresi in the polydelphic group (OrTLEPP 1937). McCluRe (1932) had examined specimens of $P$. torresi collected from A. paca and Dasyprocta leporina from the Zoological Park of New York, USA.

Four species of the genus are known parasitizing Brazilian rodent hosts. Physaloptera bispiculata Vaz \& Pereira, 1935 in Nectomys squamipes (Brants, 1827), Sigmodon hispidus Say \& Ord, 1825, Cynomys ludovicianus (Ord, 1815) and Ondatra zibethicus (Linnaeus, 1766) is represented by didelphic females with smaller dimensions than those observed in $P$. torresi. Male specimens of Physaloptera longispicula Quentin, 1968, recovered from Cercomys cunicularis Cuvier, 1829, present longer spicules, as the specific name indicates, and females remain unknown. Specimens of Physaloptera muris-brasiliensis Diesing, 1861, parasitizing Mus (Holochilus) leucogaster Brandt, 1835 (= Mus brasiliensis Desmarest, 1819) present reduced dimensions and females are didelphic; one unpaired sessile caudal papilla can be observed in the rows of the $5^{\text {th }}, 6^{\text {th }}$ and $8^{\text {th }}$ pairs.

In the identification key proposed by MoRGAN (1943), for the species of the genus recovered from rodents, the pedunculate papillae were not considered of taxonomic importance. Nevertheless, Morgan (1947) includes the number and distribution of ventral caudal papillae as well as the size of the spicules among the distinguishing characters, rejecting others, considered as intra-specific variations. The presence of an outer lateral tooth and an inner group of three teeth in the mouth was found to be common to the species of Physaloptera. ТіекоттеR (1981), besides the above-referred characters includes the study of caudal ventral ornamentations in the males (postero-ventral micro topography) by SEM.

The specimens of $P$. torresi studied here, present the typical teeth distribution referred to the genus (one outer median and three inner teeth) rectifying the descriptions of Travassos (1920), Ortlepp (1922) and McClure (1932).

In the comparison of the present morphometric data with other previously presented, adult females were slightly longer than the 70-100 reported; some different measurements related to the length of the esophagus were not taken into account because the great inter-specific variation related to this character (Morgan 1947). The size of the spicules reported by McClure (1932) was the most variable character $(0.50-0.88)$ when compared to that observed in the Brazilian samples.

Revista Brasileira de Zoologia 23 (3): 716-726, setembro, 2006 


\section{Spiruroidea, Spirocercidae Physocephalus mediospiralis (Molin, 1859) Hall, 1916} Figs $11-14$

In the three necropsies (one agouti, two pacas), nine females (two broken) and six males (two broken) were recovered.

Morphometrics based on three females (one female from agouti) and four males (all males specimens from paca) from Amazonas; four females and four males (one broken) from specimens previously deposited in CHIOC. Data in parentheses are related to the specimens of $P$. mediospiralis in pacas.

Males: body (21.42-33.52) long, (0.45-0.53) wide at middle region. Buccal capsule long, cylindrical, (0.24-0.32) long, (0.043-0.057) wide. Anterior esophagus (0.35-0.49) long, (0.068$0.072)$ wide; posterior portion (3.15-4.06) long, (0.15-0.20) wide. Nerve ring (0.364-0.448) from anterior extremity. Spicules unequal and dissimilar, the longer is slender, 2.53 (1.35-2.84) long; the shorter is stout, 0.59 (0.54-0.67) long. Gubernaculum close to the anterior extremity of the shorter spicule, (0.058) long. Cloacal opening (0.11-0.16) from the posterior extremity.

Females: body 16.97-26.15 (38.79-53.82) long, 0.48-0.77 (0.36-0.87) wide at midbody. Buccal capsule 0.23-0.25 (0.25$0.37)$ long, 0.043-0.068 (0.040-0.061) wide. Anterior esophagus $0.36-0.46(0.42-0.60)$ long, $0.079(0.070)$ wide; posterior portion 2.94-3.27 (3.29-5.58) long, 0.20 (0.14-0.15) wide. Nerve ring 0.35 (0.36-0.56) from anterior extremity. Anal opening 0.076-0.11 (0.16-0.22) from posterior end. Eggs (0.025-0.043) long, (0.011-0.043) wide. Vulvar opening 0.75 (1.05-1.48) from posterior extremity.

Taxonomic summary (samples from Amazonas). Hosts: Dasyprocta leporina (necropsy CHIOC no. 26463); site of infection: stomach; locality: Ucuqui settlement, Jauari waterway, left margin of the Rio Aracá, Barcelos municipality (GPS 00.14.25N, 63.25.00W) - NLR; collected: April 27, 2000. Agouti paca (necropsies CHIOC no. 26469-26470); site of infection: stomach; localities: Sítio da Mamãe settlement, Japomeri waterway, left margin of the Rio Padauiri, Barcelos municipality (GPS 00.20.51N, 64.00.28W); Três Barracas settlement, Jauari waterway, left margin of the Rio Aracá, Barcelos municipality NLR; collected: March 10, 2001 and February 08, 2002.

Taxonomic summary (samples from CHIOC) - Hosts: $D$. leporina (CHIOC no. 7524), Dasyprocta azarae Lichtenstein, 1823 (CHIOC no. 13180) and A. paca (CHIOC no. 10117 and 29542); site of infection: stomach; locality/date/collectors: Angra dos Reis, RJ/October, 1933/Travassos - Bodoquena, Mato Grosso do Sul/November 24, 1941/Travassos and Freitas - Jacarepaguá, RJ/May 21, 1937/Lent and Proença - Sooretama, Espírito Santo/ October 18, 1963/Travassos, Freitas and Mendonça.

Deposited specimens: CHIOC no. 7524, 13180, 10117, 29542, 34878, 34879 (wet material), 35067 a-b, 35068 a-d (whole mounts).

Remarks: Among the known physocephalids that parasitizes rodents, only P. mediospiralis (Molin, 1859) Hall, 1916 is reported from Brazilian Dasyproctidae and Agoutidae hosts. The species proposed by MoLin (1859) on the basis of nematodes recovered from specimens of Dasyprocta leporina, captured in Caiçara, Brasil, was redescribed by HALL (1916), when illustrations of the cephalic region and of the six characteristic lips of specimens of the genus were presented. Also, the copulatory bursa was described as possessing four pre-cloacal papillae and due to the tightly curved terminal portion of the body, the post-cloacal papillae together with the shorter spicule were overlooked.

Later, NoRonha et al. (2002) report the species in Dasyprocta azarae from Bodoquena, State of Mato Grosso do Sul, and in A. paca from Cachoeira do Tronco, State of Pará; Engano, Sooretama and Linhares, State of Espírito Santo and Rio de Janeiro, State of Rio de Janeiro, Brazil.

Other specimens had already been previously identified as Physocephalus sp. by Travassos (1945) in D. leporina, from the Rio Itaúnas valley, State of Espírito Santo and by Travassos \& Freitas (1948), in D. leporina and A. paca from Sooretama, State of Espírito Santo, Brazil. Nevertheless, the only available morphometric data on the species are those of Hall (1916) and López-Neyra (1951) that reproduced data after Molin (1859) when P. mediospiralis was described as Spiroptera mediospiralis; the length of males was of 26-36 long, 0.4 wide and that of females 40-46 long, 0.5 wide.

Taking into account the very few samples recovered from the agoutis and pacas during the necropsies, other specimens from the same hosts and deposited in the CHIOC were also analyzed. Even this material was not enough to clear some important aspects related to the morphology of the specimens.

In the same way, specimens of $P$. mediospiralis previously recovered from pacas and deposited in the CHIOC were examined for comparison. Great morphometric similarities were observed, when Amazonian samples were compared with those previously deposited, in despite of the difference related to the size of the slender spicule, longer in the specimens from Amazonas (2.80-2.84 for specimens from pacas captured in Amazonas; 1.35-1.40 for specimens recovered from pacas and deposited in the CHIOC).

The single male specimen of agouti analyzed, deposited in the CHIOC, presented the spicules with 2.53 and 0.59 , similarly to what was observed in specimens parasitizing the pacas from Amazonas (CHIOC no. 34878, 35068 a-d), suggesting that this species is common to both hosts. Conversely, taking into account that some specimens parasitizing pacas from the CHIOC have a smaller slender spicule (1.35-1.4), we suggest that this is due to either an intra-specific variation concerning to this character or to the presence of another unidentified species of the genus among those presently studied.

Although the comparison among the samples presently studied with those previously available in the CHIOC could not be clearly defined, the specimens presented here are provisionally related to $P$. mediospiralis, on the dependence of further studies. 


\section{Cestoda \\ Cyclophyllidea, Davaineidae, Davaineinae Raillietina (R.) trinitatae (Cameron \& Reesal, 1951) Baer \& Sandars, 1956 \\ Figs 15-18}

In the three necropsies (two agoutis, one paca), ten specimens (three broken) were recovered.

Morphometrics based on three specimens recovered from agoutis and two from pacas. Data in parentheses are related to specimens recovered from pacas.

Body 22.9-41.62 (12.38-16.46) of total length in complete specimens; maximum width 0.57-1.05 (0.34-0.82).

Number of proglottids 257-271 (199), 0.098-0.63 (0.0860.144) long, 0.378-1.05 (0.295-0.349) wide. Segmentation occurs at 0.85 from the anterior extremity. All proglottids are wider than longer, even those gravid in the posterior portion. Metamerism distinct, craspedote. Scolex 0.23-0.25 (0.28-0.32) long, 0.32 (0.35) wide, with four suckers; rostelum short, 0.10 (0.08-0.09) long, 0.11 (0.11-0.12) wide, armed with two rows of 228 (182-184) alternate hooks, 0.014-0.018 (0.014) long. Suckers 0.14-0.16 (0.083-0.09) long, 0.10-0.13 (0.11-0.12) wide, with tiny spines, disposed in rows. Neck 0.63-0.70 (0.79) long, 0.19-0.28 (0.19) wide. Ovary median, 0.094-0.35 long, 0.090.21 wide. Vitelline 0.04-0.07 long, 0.018-0.042 wide. Genital pores lateral, in the anterior half of the proglottids. Cirrus pouch small, pyriform, 0.13-0.15 long, 0.043-0.061 wide, not overpassing the osmoregulatory ducts (generic characteristic). Testes 19-50 (26-28) at the middle region of the proglottid; some of the testes overpass the ventral osmoregulatory ducts.

Number of ovigerous capsules 24-60 (24-29) in the gravid proglottids, each capsule with 9-25 eggs (absent in specimens from A. paca).

Taxonomic summary. Hosts: D. fuliginosa (necropsies CHIOC no. 26464-26465) - NHR; site of infection: small intestine; localities: Quebra Cabeça settlement, Araújo waterway, right margin of the Malalarrá waterway, right margin of the Rio Preto, Santa Isabel do Rio Negro municipality (GPS 00.03.50N, 64.35.41W) - NLR; Três Barracas settlement, Jauari waterway, left margin of the Rio Aracá, Barcelos municipality; collected in February, 26, 2001 and February, 06, 2002. Agouti paca (necropsy CHIOC no. 26469); site of infection: small intestine; locality: Sítio da Mamãe settlement, Japomeri waterway, left margin of the Rio Padauiri, Barcelos municipality (GPS 00.20.51N, 64.00.28W) - NLR; collected: March 10, 2001.

Deposited specimens: CHIOC no. 34880-34882 (wet material), 35070 a-d, 35071 a-b (whole mounts).

Remarks: The generic identification was obtained in accordance with Jones \& Bray (1994). There are three species and one subspecies of the genus Raillietina Fuhrmann, 1920, known to parasitize mammals in the neotropical region; the most common is Raillietina (R.) demerariensis (Daniels, 1895), with nu- merous synonyms and reported in several rodents, including Agouti paca, in the monkey Alouatta seniculus (Linnaeus, 1766)

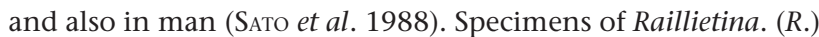
trinitatae present smaller rostelar hooks and smaller number of testes than those observed in $R$. (R.) demerariensis; the species was reported in histricognath rodents (Agouti paca and Dasyprocta leporina) from Trinidad Island, in monkeys Callicebus cupreus (Spix, 1823) and in a rodent species, Proechimys sp. from Belém, State of Pará, Brazil.

López-Neyra \& Diaz-Ungria (1957) described R. (R.) demerariensis venezolanensis recovered from the porcupine Sphiggurus insidiosus (Lichtenstein, 1818) ( = Coendou melanurus) captured in the Orinoco delta; specimens present a slightly greater number of testes when compared to the observed in $R$. (R.) demerariensis (SATO et al. 1988).

SATO et al. (1988), proposed Raillietina (R.) oligocapsulata from the rabbit Sylvilagus brasiliensis (Linnaeus, 1758) captured in Venezuela, affirming that the number of ovigerous capsules should be regarded as an important character for the specific diagnosis taking into account that the species can be easily identified by the reduced number of these capsules. In accordance with Chandler \& Pradatsundarasar (1957), the differential criteria applied to the species of Raillietina are based on the number of testes, size and number of rostelar hooks, length of the cirrus pouch, number of ovigerous capsules and number of eggs/capsule.

The specimens studied now, present a great number of rostelar hooks; Raillietina (R.) demerariensis from the paca (SATO et al. 1988, Rego 1967) is the closest species, presenting 160184 hooks, in despite that this number is similar to that of other species. Conversely, the number of testes is similar to that reported for $R$. (R.) trinitatae recovered from the agoutis and pacas (28-32 testes) studied by Cameron \& Reesal (1951) and also to the observed in $R$. (R.) demerariensis recovered from pacas and reported by SATO et al. (1988) (40-75) and by REGO (1967) (45-65). In relation to the cirrus pouch dimensions the specimens presently studied are close to both species. The number of eggs/capsule is similar to that found in $R$. (R.) demerariensis from pacas (20) as well as to the observed in $R$. (R.) trinitatae (8$12)$. The number of ovigerous capsules seems to be the most reliable differential character, since in $R$. $(R$.) demerariensis from pacas the number of capsules is extremely high (234-331) (SATO et al. 1988); 150-240 (REGO 1967), and in specimens of $R$. (R.) trinitatae this number is of 50-70, very close to that presented by the specimens studied here.

On what concerns the total length of the body, the specimens presently studied are the smallest so far reported for the species of Raillietina parasites of neotropical mammals, and closer to $R$. (R.) trinitatae (maximum length, 60). In $R$. (R.) demarariensis values for the body length are referred as 365520 (SATO et al. 1988) and 150 (REgo 1967). The reduced size of the body of the cestodes may be related to the immaturity of some specimens, since in the smallest worm, eggs were absent.

Revista Brasileira de Zoologia 23 (3): 716-726, setembro, 2006 

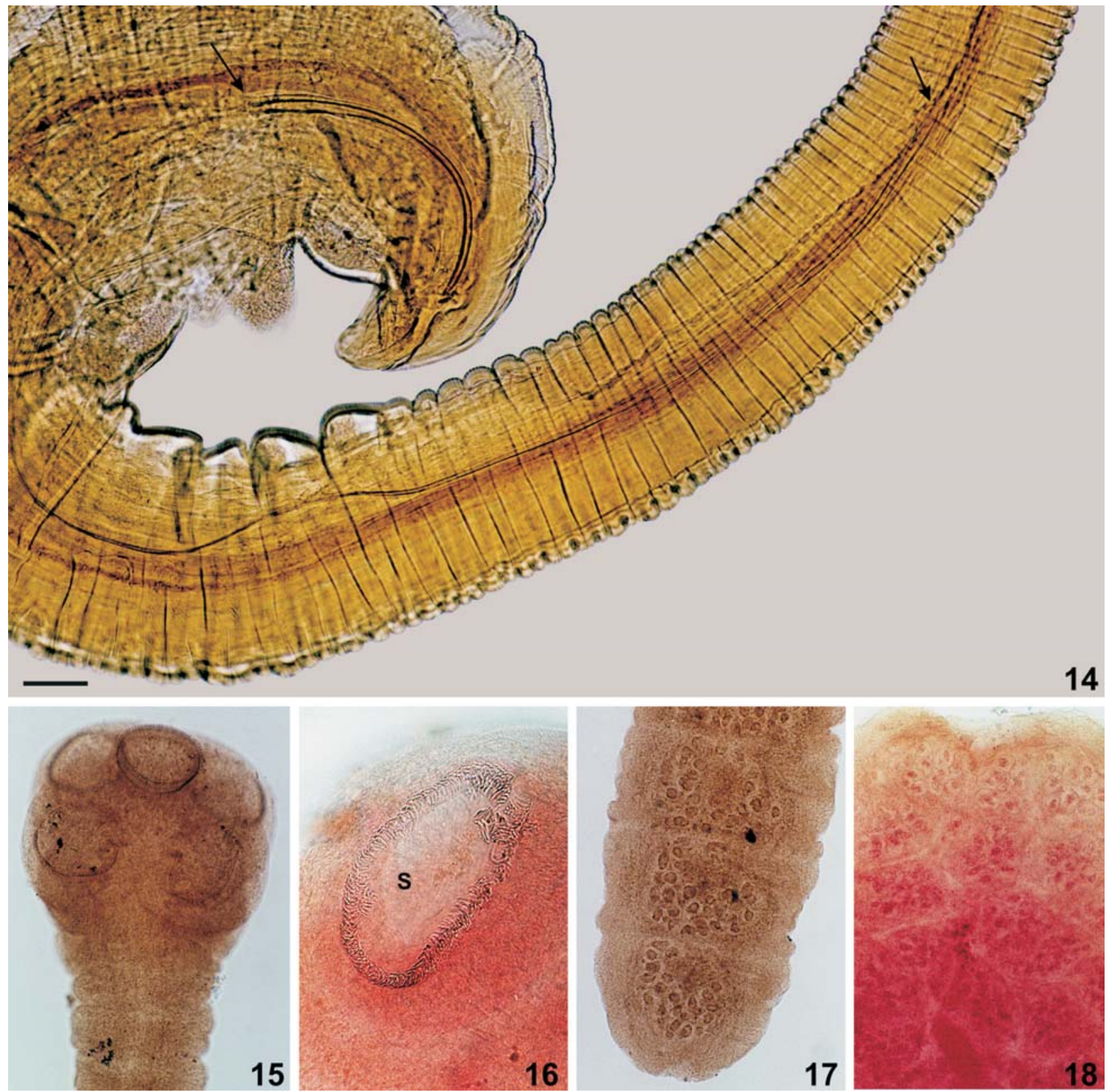

Figuras 14-18. Physocephalus mediospiralis (14) posterior portion of male, lateral view. Arrows indicate the distal portions of the spicules; Raillietina (R.) trinitatae (15) scolex with rostelum and suckers (16) detail of a sucker (S), showing the bordering spines; (17) proglottids with empty ovigerous capsules; (18) detail of a gravid proglottid with ovigerous capsules with eggs. Bar of figure 14 (common to figures $15-18)=0.04 \mathrm{~mm}$ in figures $15,17,0.05 \mathrm{~mm}$ in figure $18,0.06 \mathrm{~mm}$ in figure 16 , and $0.13 \mathrm{~mm}$ in figure 14 .

According to CAMERON \& ReESAL (1951), it seems that there are not reliable characteristics to differentiate these species, except for their size that can greatly vary together with the dimensions and number of hooks, testes and ovigerous capsules, even in specimens recovered from a same host (same population). Thus, it is believed that the species are, in fact, one, and that the specimens if not identical, share at least a common origin. Nevertheless, due to the remarkable differences in the number of ovigerous capsules that occur between the species that parasitize pacas and agoutis, the presently studied specimens were identified, only on the basis of this character, to $R$. (R.) trinitatae.

Revista Brasileira de Zoologia 23 (3): 716-726, setembro, 2006 


\section{ACKNOWLEDGMENTS}

To Angela C.V. Junqueira, Laboratory of Parasitic Diseases, Department of Tropical Medicine, Oswaldo Cruz Institute, Rio de Janeiro, Brazil for the invitation to collect the samples for this study; to the National Health Foundation for logistic support; to Cibele R. Bonvicino, National Cancer Institute, Rio de Janeiro, and Gilson E.I. Ximenes, Museum of Zoology, University of the State of São Paulo, São Paulo, Brazil, for the identification of the rodent hosts; to Dely Noronha, Curator of the Helminthological Collection, Oswaldo Cruz Institute (CHIOC), Rio de Janeiro, Brazil, for the loan of some helminth specimens for study; to Joaquim J. Vicente, Department of Helminthology, Oswaldo Cruz Institute, for the help during the taxonomic studies. Bruno E. da Silveira, Laboratory of Production and Treatment of Images, Oswaldo Cruz Institute, for the technical assistance with the photomicrograph reproduction.

\section{REFERENCES}

AмATO, J.F.R. 1985. Manual de técnicas para a preparação de coleções zoológicas. 8. Platelmintos (Temnocefálidos, Trematódeos, Cestóides, Cestodários) e Acantocéfalos. São Paulo, Sociedade Brasileira de Parasitologia, 11p.

Anderson, R.C. 1958. Méthode pour l'examen des nématodes em vue apicale. Annales de Parasitologie Humaine et Comparée, Paris, 33 (1-2): 171-172.

Cameron, T.W.M.; M.R. Reesal 1951. Studies on the endoparasitic fauna of Trinidad mammals. VII. Parasites of hystricomorph rodents. Canadian Journal of Zoology, Otawa, 29: 276-289.

Chabaud, A.G.; A. Petter. 1961. Remarques sur l'évolution des papilles cloacales chez les nématodes phasmidiens parasites de vertébrés. Comptes Rendus de l'Académie des Sciences, Paris, 252: 1684-1686.

Chandler, A.C.; A. Pradatsundarasar. 1957. Two cases of Raillietina infection in infants in Thailand, with a discussion of the taxonomy of the species of Raillietina (Cestoda) in man, rodents and monkeys. Journal of Parasitology, Lawrence, 43 (1): 81 89.

Gomes, D.C.; R.M. PInTo. 1978. Contribuição ao conhecimento da fauna helmintológica da Região Amazônica - Trematódeos. Atas da Sociedade de Biologia do Rio de Janeiro, Rio de Janeiro, 19: 43-46.

Gonçalves, A.Q.; J.J. Vicente; R.M. Pinto. 2002. Nematodes of Amazonian vertebrates deposited in the Helminthological Collection of the Oswaldo Cruz Institute with new records. Revista Brasileira de Zoologia, Curitiba, 19 (2): 453-465.

HALL, M.C. 1916. Nematode parasites of mammals of the orders Rodentia, Lagomorpha, and Hyracoidea. Proceedings of the United States National Museum, Washington, 50: 1-258.

Hugot, J.P. 1986. Étude morphologique d' Helminthoxys urichi (Oxyurata, Nematoda) parasite de Dasyprocta aguti (Caviomorpha, Rodentia). Bulletin du Muséum National d'Histoire Naturelle, Paris, $4^{\mathrm{e}}$ ser., Section A, 8 (1): 133-138.
Jones, A. \& R.A. Bray. 1994. Family Davaineidae Braun, 1900, p. 407-441. In: L.F. Khalil; A. Jones \& R.A. Bray (Eds). Keys to the cestode parasites of vertebrates. Wallingford, CABI Publishing, 751p.

López-Neyra, C.R. 1951. Los Ascaropsinae (Nematoda-Spirurata). Revista Ibérica de Parasitologia, Granada, 11 (2): 289-223.

López-Neyra, C.R.; C. Diaz-Ungria. 1957. Cestodes de Venezuela. III. Sobre unos cestodes intestinales de reptiles y mamiferos venezolanos. Memoria de la Sociedad de Ciencias Naturales La Salle, Caracas, 17: 28-63.

McCluRE, G.W. 1932. Nematode parasites of mammals with a description of a new species, Wellcomia branickii from specimens collected in the New York Zoological Park, 1930. Zoologica, Cheyenne, 15 (1): 1-28.

Molin, R. 1859. Una monografia del genere Spiroptera. Sitzbericht Akademy für Wissenschaft, Berlin, 38: 911-1005.

Morgan, B.B. 1943. The Physaloptera (Nematoda) of rodents.The Wasmann Collector, San Francisco, 5: 99-107.

Morgan, B.B. 1947. Host-parasite relationships and geographical distribution of the Physalopterinae (Nematoda). Transactions of the Wisconsin Academy of Sciences, Arts and Letters, Illinois, 38: 273-292.

Noronha, D.; J.J. Vicente \& R.M. Pinto. 2002. A survey of new host records for nematodes from mammals deposited in the Helminthological Collection of the Oswaldo Cruz Institute (CHIOC). Revista Brasileira de Zoologia, Curitiba, 19 (3): 945-949.

Ortlepp, R.J. 1922. The nematode genus Physaloptera Rud. Proceedings of the Zoological Society of London, London, 2: 999-1107.

OrtLepr, R.J. 1937. Some Undescribed Species of the Nematode Genus Physaloptera Rud., together with a Key to the Sufficiently Known Forms. Onderstepoort Journal of Veterinary Science and Animal Industry, Onderstepoort, 9 (1): 71-84.

Pereira, R.C.S.; D.A. Machado-Filho. 1968. Nota prévia sobre o alótipo fêmea de "Subulura interrogans" Lent \& Freitas, 1935 e descrição de "Subulura amazonica" sp. n. (Nematoda, Subuluridae). Atas da Sociedade de Biologia do Rio de Janeiro, Rio de Janeiro, 12 (1): 11-12.

PINTO, R.M. \& D.C. GomEs. 1976. Contribuição ao conhecimento da fauna helmintológica da região amazônica - cestódeos. Memórias do Instituto Oswaldo Cruz, Rio de Janeiro, 74 (1): 53-64.

PINTO, R.M. \& D.C. Gomes. 1980. Contribuição ao conhecimento da fauna helmintológica da região amazônica. Nematódeos. Atas da Sociedade de Biologia do Rio de Janeiro, Rio de Janeiro, 21: 65-74.

PINTO, R.M. \& D.C. Gomes. 1984. Nematodes of Amazonian birds, with a description of Hoazinstrongylus amazonensis n.gen. n.sp (Trichostrongylidae, Libyostrongylinae). Memórias do Instituto Oswaldo Cruz, Rio de Janeiro, 80 (2): 213-217.

RegO, A.A. 1967. Sobre alguns cestódeos parasitos de roedores 
do Brasil (Cestoda, Cyclophyllidea). Memórias do Instituto Oswaldo Cruz, Rio de Janeiro, 65 (1): 1-18.

RudolphI, C.A. 1819. Entozoorum synopsis cui accedunt mantissa duplex et indices locupletissimi. Berolina, $\mathrm{X}+811 \mathrm{p}$.

Sato, H., M. Oкамoto, M. Ohbayashi, M.G. Basáñez. 1988. A new cestode, Raillietina (Raillietina) oligocapsulata sp. nov., and $R$. (R.) demerariensis (Daniels, 1895) from Venezuelan mammals. Japanese Journal of Veterinary Research, Tokyo, 36: 31-45. Thнтснек, V.E. 1991. Amazon fish parasites. Amazoniana, Kiel, 11 (3/4): 263-572.

Tiekotтer, K.L. 1981. Observations of the head and tail regions of male Physaloptera praeputialis von Linstow, 1889, and Physaloptera rara Hall and Wigdor, 1918, using scanning electron microscopy. Proceedings of the Helminthological Society of Washington, Washington, 48 (2): 130-136.

Travassos, L. 1920. Contribuições para o conhecimento da fauna helmintológica brasileira. Memórias do Instituto Oswaldo Cruz, Rio de Janeiro, 12 (1): 73-77.

Travassos, L. 1945. Relatório da excursão realizada no Vale do Rio Itaúnas, norte de Estado do Espírito Santo, nos meses de setembro e outubro de 1944. Memórias do Instituto Oswaldo Cruz, Rio de Janeiro, 42 (3): 487-502.

Travassos, L. \& J.F.T. Freitas. 1948. Relatório da excursão do Instituto Oswaldo Cruz ao norte do Estado do Espírito Santo, junto ao Parque Reserva e Refúgio Sooretama, em fevereiro de 1948. Memórias do Instituto Oswaldo Cruz, Rio de Janeiro, 46 (3): 605-631.

Vicente, J.J. 1964. Nova espécie do gênero "Aspidodera" Railliet \& Henry, 1912 (Nematoda, Subuluroidea). Revista Brasileira de Biologia, Rio de Janeiro, 24 (3): 317-320.

Vicente, J.J.; H.O. Rodrigues; D.C.Gomes \& R.M. Pinto.1997. Nematóides do Brasil. Parte V: Nematóides de mamíferos. Revista Brasileira de Zoologia, Curitiba, 14 (Supl. 1): 1-452.

Received in 18.XI.2005; accepted in 21.VIII.2006.

Revista Brasileira de Zoologia 23 (3): 716-726, setembro, 2006 